\title{
Al-Y-Zr (Aluminum-Yttrium-Zirconium)
}

\section{Raghavan}

Recently, [2010She] determined an isothermal section for this system at $500{ }^{\circ} \mathrm{C}$, which shows no ternary phases.

\section{Binary Systems}

The Al-Y phase diagram [Massalski2] has the following intermediate phases: $\alpha \mathrm{Al}_{3} \mathrm{Y}\left(\mathrm{D0}_{19}, \mathrm{Ni}_{3} \mathrm{Sn}\right.$-type hexagonal), $\mathrm{BAl}_{3} \mathrm{Y}\left(\mathrm{BaPb}_{3}\right.$-type rhombohedral), $\mathrm{Al}_{2} \mathrm{Y}\left(C 15, \mathrm{MgCu}_{2}-\right.$ type cubic), AlY ( $B_{f}$, CrB-type orthorhombic), $\mathrm{Al}_{2} \mathrm{Y}_{3}$ $\left(\mathrm{Al}_{2} \mathrm{Zr}_{3}\right.$-type tetragonal), and $\mathrm{AlY}_{2}\left(C 23, \mathrm{Co}_{2} \mathrm{Si}\right.$-type orthorhombic). The Al-Zr phase diagram [Massalski2] depicts the following intermediate phases: $\mathrm{Al}_{3} \mathrm{Zr}\left(\mathrm{DO}_{23}\right.$-type tetragonal), $\mathrm{Al}_{2} \mathrm{Zr}\left(C 14, \mathrm{MgZn}_{2}\right.$-type hexagonal), $\mathrm{Al}_{3} \mathrm{Zr}_{2}\left(\mathrm{Al}_{3} \mathrm{Zr}_{2}-\right.$ type orthorhombic), AlZr ( $B_{f}$, CrB-type orthorhombic), $\mathrm{Al}_{4} \mathrm{Zr}_{5}\left(\mathrm{Ga}_{4} \mathrm{Ti}_{5}\right.$-type hexagonal), $\mathrm{Al}_{3} \mathrm{Zr}_{4}\left(\mathrm{Al}_{3} \mathrm{Ir}_{4}\right.$-type hexagonal), $\quad \mathrm{Al}_{2} \mathrm{Zr}_{3} \quad\left(\mathrm{Al}_{2} \mathrm{Zr}_{3}\right.$-type tetragonal), $\mathrm{Al}_{3} \mathrm{Zr}_{5}$ $\left(D 8_{m}, \mathrm{~W}_{5} \mathrm{Si}_{3}\right.$-type tetragonal), $\mathrm{AlZr}_{2}\left(B 8_{2}, \mathrm{Ni}_{2}\right.$ In-type hexagonal), and $\mathrm{AlZr}_{3}\left(L 1_{2}, \mathrm{AuCu}_{3}\right.$-type cubic). The $\mathrm{Y}-\mathrm{Zr}$ phase diagram [Massalski2] contains no intermediate phases. The solid solubility in the terminal phases is limited.

\section{Ternary Isothermal Section}

With starting metals of $99.99 \% \mathrm{Al}, 99.95 \% \mathrm{Y}$ and 99.95\% Zr, [2010She] arc-melted 66 alloys under Ar atm. The samples were given a final anneal at $500{ }^{\circ} \mathrm{C}$ for $240 \mathrm{~h}$ and quenched in liquid nitrogen. The phase equilibria were studied $\mathrm{x}$-ray powder diffraction and scanning electron microscope equipped with energy dispersive $\mathrm{x}$-ray analyzer. The isothermal section at $500{ }^{\circ} \mathrm{C}$ constructed by [2010She] is shown in Fig. 1. No ternary phases were found. The

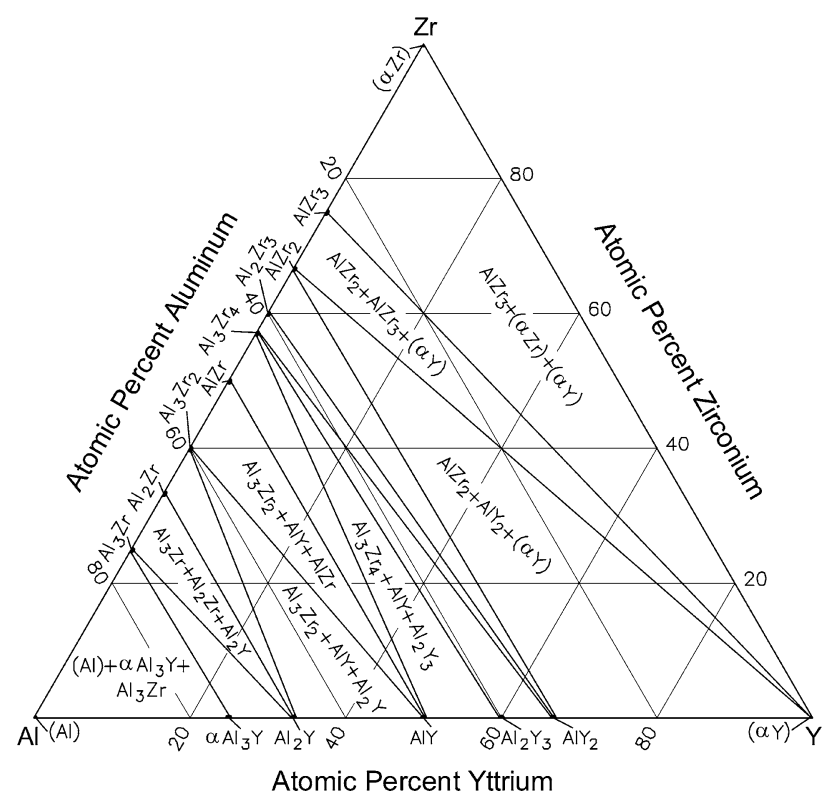

Fig. 1 Al-Y-Zr isothermal section at $500{ }^{\circ} \mathrm{C}$ [2010She]. Narrow two-phase regions are omitted

ternary solubility in the binary compounds was found to be negligible. The binary compounds $\mathrm{Al}_{4} \mathrm{Zr}_{5}$ and $\mathrm{Al}_{3} \mathrm{Zr}_{5}$ are not stable at $500{ }^{\circ} \mathrm{C}$.

\section{Reference}

2010She: J. She, Y. Zhan, Z. Hu, C. Li, J. Hu, Y. Du, and H. Xu, Experimental Study of Al-Zr-Y System Phase Equilibria at 773 K, J. Alloys Compd., 2010, 497, p 118-120 